\title{
Diet components as internal indicators in the determination of the apparent digestibility coefficients for Nile tilapia
}

\author{
Rafael Lopes da Silva(1), Eric Portilho de Araújo(1), Mariucha Karina Honório Ribeiro Rocha( ${ }^{(1)}$, \\ Flavia Mota Damasceno(1), Jakeline Marcela Azambuja de Freitas ${ }^{(1)}$, Maria Márcia Pereira Sartori(2), \\ Paulo Roberto de Lima Meirelles ${ }^{(1)}$, Margarida Maria Barros( ${ }^{(1)}$ and Luiz Edivaldo Pezzato(1)
}

\begin{abstract}
(1)Universidade Estadual Paulista Júlio de Mesquita Filho (Unesp), Faculdade de Medicina Veterinária e Zootecnia, Departamento de Melhoramento e Nutrição Animal, Fazenda Experimental Lageado, Caixa Postal 560, CEP 18618-000 Botucatu, SP, Brazil. E-mail: silvarl@outlook.com,eric.portilho@outlook.com,mariucharocha@yahoo.com.br,fmdamasceno@icloud.com,jakelinemarcela@hotmail.com, paulom@fmvz.unesp.br, mbarros@fmvz.unesp.br, epezzato@fmvz.unesp.br (2)Unesp, Faculdade de Ciências Agronômicas, Departamento de Produção e Melhoramento Vegetal, Fazenda Experimental Lageado, Caixa Postal 237, CEP 18610-307 Botucatu, SP, Brazil. E-mail: mmpsartori@fca.unesp.br
\end{abstract}

Abstract - The objective of this work was to evaluate the diet components - crude fiber, neutral detergent fiber, acid detergent fiber, hemicellulose, cellulose, and lignin - as internal indicators in the determination of the apparent digestibility coefficients of dry matter, gross energy, and of the nutrients - crude protein, phosphorus, and amino acids - in Nile tilapia (Oreochromis niloticus). Groups of ten juveniles ( $80.3 \pm 1 \mathrm{~g})$ were randomly distributed in six tanks of $250 \mathrm{~L}$ and fed two practical diets, either of a plant-origin diet or of a plant- and animal-origin diet. Both diets were supplemented with $0.1 \%$ chromium (III) oxide $\left(\mathrm{Cr}_{2} \mathrm{O}_{3}\right)$. Faeces were collected by the modified Guelph system. The apparent digestibility coefficients were determined by the content difference of the internal indicators, present in the diets and faeces, and compared by Dunnett's test to those obtained by the use of $\mathrm{Cr}_{2} \mathrm{O}_{3}$. Cellulose was effective in the determination of the apparent digestibility of dry matter, energy, and nutrients of both experimental diets; and the acid detergent fiber was effective only for the diet composed exclusively of plant-origin ingredients. The use of crude fiber, neutral detergent fiber, hemicellulose, and lignin as digestibility indicators was inefficient for the analyzed nutrients of both diets. Therefore, cellulose is the most suitable indicator for digestibility evaluation in Nile tilapia.

Index terms: Oreochromis niloticus, cellulose, fiber, nutrients.

\section{Componentes da dieta como indicadores internos na determinação dos coeficientes de digestibilidade aparente em tilápia-do-nilo}

Resumo - O objetivo deste trabalho foi avaliar os componentes da dieta-fibra bruta, fibra em detergente neutro, fibra em detergente ácido, hemicelulose, celulose e lignina - como indicadores internos na determinação dos coeficientes de digestibilidade aparente da matéria seca, da energia bruta e dos nutrientes - proteína bruta, fósforo e aminoácidos - em tilápia-do-nilo (Oreochromis niloticus). Grupos de dez juvenis $(80,3 \pm 1 \mathrm{~g})$ foram aleatoriamente distribuídos em seis tanques de $250 \mathrm{~L}$ e alimentados com duas dietas práticas, ou com ingredientes de origem vegetal ou de origem vegetal e animal. Ambas as dietas foram suplementadas com $0,1 \%$ de óxido de cromo-III $\left(\mathrm{Cr}_{2} \mathrm{O}_{3}\right)$. As fezes foram coletadas pelo sistema Guelph modificado. Os coeficientes de digestibilidade aparente foram determinados pela diferença de teor dos indicadores internos, presentes nas dietas e nas fezes, e comparados, pelo teste de Dunnett, aos obtidos pelo uso de $\mathrm{Cr}_{2} \mathrm{O}_{3}$. A celulose foi efetiva na determinação dos coeficientes de digestibilidade aparente da matéria seca, da energia e dos nutrientes de ambas as dietas; e a fibra em detergente ácido foi efetiva apenas para a dieta que continha exclusivamente ingredientes de origem vegetal. A utilização de fibra bruta, fibra em detergente neutro, hemicelulose e lignina, como indicadores de digestibilidade, mostrou-se ineficiente quanto aos nutrientes analisados de ambas as dietas. Assim, a celulose é o indicador mais apropriado para a avaliação de digestibilidade em tilápia-do-nilo.

Termos para indexação: Oreochromis niloticus, celulose, fibra, nutrientes.

\section{Introduction}

In intensive animal farming, feed is the main or exclusive source of nutrients for fish, accounting for $50-70 \%$ of production costs (Guimarães et al., 2008a). However, the use of feeds that are not properly balanced reduces the absorption of nutrients by fish, which results in excess organic 
matter in the production systems. Under tropical conditions, this excess is rapidly mineralized and becomes readily available for phytoplankton growth, with a consequent decrease of water transparency and change of water quality. As a result, a decrease occurs in the concentration of dissolved oxygen, especially at night, leading to respiratory and biochemical stresses that induce to serious fish health risks, and to possible production losses (Cyrino et al., 2010).

Nile tilapia is the sixth most cultivated fish species in the world (Michelato et al., 2013; Tacon \& Metian, 2013) and the most cultivated one in Brazil. In the country, the animal feed industry certifies the feed quality by the performance responses obtained mainly by weight gain and apparent feed conversion. Unfortunately, the apparent digestibility coefficient of the nutrients is not determinant in the choice of feeds, whether due to the absence of these values as a rule, or to the difficulty of obtaining them, without reprocessing the feeds, for the inclusion of an external indicator of digestibility.

Determining the values for apparent digestibility coefficients by dietary components would enable investigations of the nutritional value of commercial feeds, which could help with the development of lowpolluting feeds. In this sense, some components have been evaluated and used as indicators of internal digestibility for fish, such as crude fiber (Morales et al., 1999; Vidal Junior et al., 2004; Krontveit et al., 2014), neutral detergent fiber (Furuya et al., 2004), acid detergent fiber (Vidal Junior et al., 2004), hydrolysis-resistant organic matter (Buddington, 1980), acid-insoluble ash (Vidal Junior et al., 2004; Li et al., 2008; Da et al., 2013) and acid-detergent insoluble ash (Vidal Junior et al., 2004). However, the use of these components remains contradictory because the chemical composition of the evaluated diet may affect the obtained coefficients (Morales et al., 1999).

The objective of this work was to evaluate the diet components - crude fiber (CF), neutral detergent fiber (NDF), acid detergent fiber (ADF), hemicellulose, cellulose, and lignin - as internal indicators in the determination of apparent digestibility coefficients (ADC) of dry matter (DM), gross energy, and of the nutrients - crude protein (CP), phosphorus, and amino acids - in Nile tilapia.

\section{Materials and Methods}

The experiment was carried out at the laboratory for nutrition of aquatic organisms (AquaNutri) of Faculdade de Medicina Veterinária e Zootecnia, Universidade Estadual Paulista Júlio de Mesquita Filho, in the municipality of Botucatu, in the state of São Paulo, Brazil. The adopted procedures were approved by the institution's animal ethics committee (CEUA), with the protocol No. 132/2014.

To meet the Nile tilapia nutritional requirements (Furuya, 2010), two practical diets were prepared: the first one was made exclusively with plant-origin ingredients, and the second one was made with animaland plant-origin ingredients (Table 1). Chromium (III) oxide $\left(\mathrm{Cr}_{2} \mathrm{O}_{3}\right)$ at $0.1 \%(\mathrm{~m} / \mathrm{m})$ was added to both diets, and used as the standard external indicator, which is widely used in fish digestibility assays (Guimarães et al., 2008b, 2008c; Xavier et al., 2014; Vidal et al., 2015).

For the preparation of the feeds, all ingredients were milled ( $0.4 \mathrm{~mm}$ diameter), weighed, and homogenized.

Table 1. Composition of the experimental diets.

\begin{tabular}{|c|c|c|}
\hline \multirow[t]{2}{*}{ Ingredient $(\%)$} & \multicolumn{2}{|c|}{ Diet } \\
\hline & $\mathrm{PD}^{(1)}$ & $\mathrm{APD}^{(2)}$ \\
\hline Soybean meal & 48.1 & 43.62 \\
\hline Corn gluten & 4.5 & - \\
\hline Meat and bone meal & - & 4 \\
\hline Poultry by-product meal & - & 6 \\
\hline Corn & 33.96 & 33.96 \\
\hline Wheat middlings & 10 & 10 \\
\hline Soybean oil & 0.19 & 0.11 \\
\hline L-Lysine & 0.22 & 0.02 \\
\hline DL-Methionine & 0.31 & 0.26 \\
\hline L-Threonine & 0.33 & 0.31 \\
\hline Dicalcium phosphate & 1.63 & 0.96 \\
\hline Sodium chloride $(\mathrm{NaCl})$ & 0.1 & 0.1 \\
\hline Premix - vitamin and mineral $\operatorname{mix}^{(3)}$ & 0.5 & 0.5 \\
\hline Vitamin $C^{(4)}$ & 0.04 & 0.04 \\
\hline Antioxidant $(\mathrm{BHT})^{(5)}$ & 0.02 & 0.02 \\
\hline Chromium (III) oxide & 0.1 & 0.1 \\
\hline
\end{tabular}

${ }^{(1)} \mathrm{PD}$, diet containing exclusively plant-origin ingredients. (2) $\mathrm{APD}$, diet containing animal- and plant-origin ingredients. ${ }^{(3)}$ Premix (Tectron, Toledo, PR), vitamin and mineral mix (kg of product): vitamin A, 1,000,000 IU; vitamin $\mathrm{D}_{3}, 500,000 \mathrm{IU}$; vitamin E, 20,000 IU; vitamin $\mathrm{K} 3,500 \mathrm{mg}$; vitamin $B_{1}, 1,900 \mathrm{mg}$; vitamin $B 2,2,000 \mathrm{mg}$; vitamin $B_{6}, 2,400 \mathrm{mg}$; vita$\min \mathrm{B} 12,3,500 \mathrm{mcg}$; vitamin C, $25 \mathrm{~g}$; niacin, $5,000 \mathrm{mg}$; calcium pantothenate, 4,800 mg; folic acid, $200 \mathrm{mg}$; biotin, $40 \mathrm{mg}$; Mn, 7,500 mg; Zn, 25 $\mathrm{g}$; Fe, $12.5 \mathrm{~g}$; Cu, 2,000 mg; I, $200 \mathrm{mg}$; Se, $70 \mathrm{mg}$; antioxidant, $300 \mathrm{mg} .{ }^{(4)}$ Vitamin C Rovimix Stay-35 (DMS Nutritional Products, Switzerland). ${ }^{(5)}$ Butylated hydroxytoluene (antioxidant). 
After the addition of water at $55^{\circ} \mathrm{C}(20 \%$ of the total mass), the mixtures were extruded (Exteec, Ribeirão Preto, SP, Brazil). Subsequently, the mixtures were dried in an oven at $55^{\circ} \mathrm{C}$, for 24 hours, and stored in labelled plastic containers in a cold chamber $\left(5^{\circ} \mathrm{C}\right)$ until use. The composition of the diets are shown in the Tables 1 and 2.

For fish feeding, six circular fiberglass tanks (250 L), connected to a physical and biological filter with a continuous water-recirculation system, were used. For the collection of faeces, six cylindrical fiberglass

Table 2. Composition of the experimental diets on a drymatter basis.

\begin{tabular}{|c|c|c|}
\hline \multirow[t]{2}{*}{ Composition } & \multicolumn{2}{|c|}{ Diet } \\
\hline & $\mathrm{PD}^{(1)}(\%)$ & $\mathrm{APD}^{(2)}(\%)$ \\
\hline Dry matter & 94.36 & 93.98 \\
\hline Gross energy $\left(\mathrm{kcal} \mathrm{kg}^{-1}\right)$ & 4,390 & 4,338 \\
\hline Crude protein & 31.76 & 32.18 \\
\hline Ether extract & 3.29 & 4.18 \\
\hline Ash & 5.60 & 6.91 \\
\hline Phosphorus & 0.80 & 1.10 \\
\hline \multicolumn{3}{|l|}{ Essential amino acids } \\
\hline Arginine & 2.26 & 2.43 \\
\hline Histidine & 0.74 & 0.97 \\
\hline Isoleucine & 0.95 & 0.85 \\
\hline Leucine & 2.84 & 2.50 \\
\hline Lysine & 1.99 & 1.97 \\
\hline Phenylalanine & 1.47 & 1.39 \\
\hline Methionine & 0.52 & 0.61 \\
\hline Threonine & 1.13 & 1.31 \\
\hline Tryptophan & 0.28 & 0.23 \\
\hline Valine & 0.93 & 0.96 \\
\hline \multicolumn{3}{|l|}{ Nonessential amino acids } \\
\hline Alanine & 1.67 & 1.76 \\
\hline Aspartic acid & 3.14 & 3.18 \\
\hline Cystine & 0.67 & 0.45 \\
\hline Glycine & 1.77 & 2.49 \\
\hline Glutamic acid & 6.09 & 5.84 \\
\hline Proline & 2.79 & 2.88 \\
\hline Serine & 1.66 & 1.62 \\
\hline Tyrosine & 0.74 & 0.74 \\
\hline \multicolumn{3}{|l|}{ Indicator } \\
\hline Chromium (III) oxide & 0.10 & 0.10 \\
\hline Crude fiber & 4.33 & 4.46 \\
\hline Neutral detergent fiber & 19.19 & 21.56 \\
\hline Acid detergent fiber & 6.78 & 8.61 \\
\hline Hemicellulose & 12.41 & 12.95 \\
\hline Cellulose & 5.00 & 6.25 \\
\hline Lignin & 0.87 & 0.80 \\
\hline
\end{tabular}

(1) $\mathrm{PD}$, diet containing exclusively plant-origin ingredients. (2) PAD, diet containing animal- and plant-origin ingredients. tanks of $300 \mathrm{~L}$, each with a conical bottom, were used, with a physical-biological filter and individual water recirculation system. The physicochemical parameters of water, such as $\mathrm{pH}(6.66 \pm 0.04)$ and dissolved oxygen $\left(6.23 \pm 0.22 \mathrm{mg} \mathrm{L}^{-1}\right)$ were measured weekly using a YSI-556 multiparameter probe (YSI Environmental, Yellow Spring, OH, USA). Total ammonia content $(0.002 \pm 0.000 \mathrm{ppm})$ was measured weekly using a Labcon commercial kit (Alcon, Camboriú, SC, Brazil). The temperature was measured daily $\left(25.3 \pm 0.5^{\circ} \mathrm{C}\right)$. The photoperiod was of 12 hours, and it was controlled with fluorescent lamps.

Masculinized juveniles of Nile tilapia $(80.3 \pm 1 \mathrm{~g})$ were stocked (ten fish per cage) in six cylindrical cages of $120 \mathrm{~L}$ made of a plastic screen $(1.5 \mathrm{~cm}$ mesh). The cages, placed in the feeding tanks, were used to house fish and to facilitate handling between the feeding and fecal collection tanks. For seven days, fish remained in the feeding tanks for adaptation to the handling and to the feeds, which were given four times a day - at 8:00, 11:00, 14:00, and 15:00 $\mathrm{h}$ until apparent satiation.

Subsequently, the feed was supplied hourly (from 8:00 to 5:00 h); at the end of the day $(6: 00 \mathrm{~h})$, fish were transferred to the fecal collection tanks, where they remained overnight. In the morning of the following day $(8: 00 \mathrm{~h})$, fish were returned to their respective feeding tanks, and faeces were collected with sampling vials $(200 \mathrm{~mL})$ connected to the bottom of the collection tanks. This procedure was carried out for 14 days, which allowed of the obtention of a representative fecal volume for the chemical-nutritional analysis $( \pm 6 \mathrm{~g}$ per tank, in the DM basis). The collected faeces were dehydrated in an oven at $55^{\circ} \mathrm{C}$, for 48 hours, ground, and stored at $-20^{\circ} \mathrm{C}$.

The determinations of DM, CP, ether extract, and mineral matter of the feeds and faeces were performed according to the methodologies described by AOAC (Silva \& Queiroz, 2006). Gross energy was estimated by the combustion of samples in a bomb calorimeter C200 (IKA, Staufen, BW, Germany). Phosphorus was quantified by the vanadomolybdophosphoric acid method (Moraes et al., 2009). Amino acid analysis was performed by high-performance liquid chromatography (HPLC) at the laboratory CBO Análises Laboratoriais (Campinas, SP, Brazil).

The indicators were determined as below described. Crude fiber was quantified by the Weende method (Silva \& Queiroz, 2006), whereas the NDF, ADF, 
cellulose, and lignin were measured according to the sequential methodology described by Van Soest et al. (1991). The hemicellulose content was obtained by the equation (NDF - ADF). The content of chromium (III) oxide was determined according to the methodology of Bremer Neto et al. (2005).

The calculations of the ADCs of the DM, energy, and nutrients ( $\mathrm{CP}$, phosphorus, and amino acids) of the experimental diets were carried out using the external $\mathrm{Cr}_{2} \mathrm{O}_{3}$ standard indicator, and the calculations of the remaining internal indicators were performed using the equations described by Maynard \& Loosli (1969) and Bureau \& Hua (2006), respectively, as follows: $\mathrm{ADC}_{\mathrm{DM}}=1-\left(\mathrm{I}_{\mathrm{d}} / \mathrm{I}_{\mathrm{f}}\right)$, in which $\mathrm{ADC}_{\mathrm{DM}}$ is the apparent DM digestibility coefficient, $I_{d}$ is the indicator percentage in the diet, and $\mathrm{I}_{\mathrm{f}}$ is the indicator percentage in the faeces. Furthermore, $A D C N=1-\left[\left(\mathrm{I}_{\mathrm{d}} / \mathrm{I}_{\mathrm{f}}\right) \times\left(\mathrm{N}_{\mathrm{f}} / \mathrm{N}_{\mathrm{d}}\right)\right]$, in which $\mathrm{ADC}_{\mathrm{N}}$ is the ADC of the nutrient, $\mathrm{I}_{\mathrm{d}}$ is the indicator percentage in the diet, $\mathrm{I}_{\mathrm{f}}$ is the indicator percentage in the faeces, $\mathrm{N}_{\mathrm{f}}$ is the nutrient percentage (or kcal $\mathrm{kg}^{-1}$ gross energy) in the faeces, and $\mathrm{N}_{\mathrm{d}}$ is the nutrient percentage (or kcal kg-1 gross energy) in the diet.

The experiment was carried out in a completely randomized design in a split-plot arrangement, with repeated measures, and three replicates for each diet. The plots consisted of the two diets, and the subplots consisted of the seven digestibility indicators.

Data were previously analyzed for normality by the Shapiro-Wilk's test, and based on this premise, they were subjected to the analysis of variance for the onefactor model, at $5 \%$ probability. The Dunnett's test was used to compare the ADC means, obtained when using the standard external indicator $\mathrm{Cr}_{2} \mathrm{O}_{3}$, to those means provided by the evaluated internal indicators. The analyses were performed by the Minitab statistical software, version 16 (Minitab, Inc., State College, PA, USA).

\section{Results and Discussion}

The diet with animal- and plant-origin ingredients showed a higher percentage of CF, NDF, ADF, hemicellulose, and cellulose than the diet containing exclusively plant-origin ingredients (Table 2). This result may be associated with the ingredients meatand-bone meal and poultry by-product meal, whose inclusion, although at lower levels than the maximum recommended one for the species (Hernández et al.,
2010; Abimorad et al., 2014), may have affected the determination of the obtained values due to the chemical composition of these ingredients, which comprised a high content of ether extract and mineral matter (Van Soest et al., 1991).

The ADF compared with the values obtained with the $\mathrm{Cr}_{2} \mathrm{O}_{3}$ standard indicator provided an adequate determination of the ADCs of the DM, energy, and nutrients of the diet that exclusively contained ingredients of plant origin (Table 3). However, there is a result reported on a study on tambaqui (Colossoma macropomum) whose ADF provided values which differed from those obtained with $\mathrm{Cr}_{2} \mathrm{O}_{3}$, when the digestibility coefficients of $\mathrm{DM}$ and $\mathrm{CP}$ of finely ground corn and soybean meal were evaluated (Vidal Junior et al., 2004). Like ADF, the use of cellulose as an indicator of digestibility provided similar ADCs for the DM, energy, and nutrients in the diet with plantorigin ingredients only (Table 3 ), in comparison with the values obtained by using the external standard indicator $\mathrm{Cr}_{2} \mathrm{O}_{3}$.

In the determination of ADC and cellulose of the diet with animal- and plant-origin ingredients, it was observed that $\mathrm{ADF}$ provided values lower than those obtained using $\mathrm{Cr}_{2} \mathrm{O}_{3}$ for the DM, energy, and nutrients $(p<0.05)$, while the cellulose provided lower values only for $\mathrm{CP}$ and for the essential amino acids phenylalanine and valine $(p<0.05)$ (Table 4$)$. The ADF consists mostly of cellulose and lignin, and it is basically used as a pre-extracted material for the determination of lignin, by the methods of acid detergent lignin or potassium permanganate lignin (Silva \& Queiroz, 2006). Although Saha et al. (2006) reported the isolation of bacteria strains with cellulase activity, in the intestine of Mozambique tilapia (O. mossambicus), the coefficients obtained with the $\mathrm{ADF}$ and cellulose in the present study for the diet with exclusively plant-origin ingredients indicate that no degradation occurred in these components by Nile tilapia. The lower ADCs provided by using ADF and cellulose (for $\mathrm{CP}$ and the amino acids phenylalanine and valine) as indicators of diet digestibility, with animal- and plant-origin ingredients, may be attributed to the influence of the meat-and-bone meal and poultry by-product meal on the values (Van Soest et al., 1991).

The use of CF, in comparison with the data obtained with $\mathrm{Cr}_{2} \mathrm{O}_{3}$ resulted in higher ADCs for the DM, energy, and nutrients for both diets $(\mathrm{p}<0.05)$ (Tables 3 and 4$)$. 
Crude fiber does not represent a homogeneous group of substances, as it is composed mainly of nonstarch polysaccharides (NSP) (Goñi et al., 2009). The NSP fraction can be classified as insoluble (cellulose and hemicellulose) and soluble (pectins, gums, and mucilages), according to its solubility in water. The soluble NSP is digestible during the passage through the digestive tract (Amirkolaie et al., 2005; Krogdahl et al., 2005). In the present study, the ADC of the NSP fraction was not determined. However, according to the coefficients provided by the $\mathrm{CF}$ as an indicator of digestibility, it is possible that NSP fraction has not undergone degradation. Determination of the CF by the Weende's method may have affected the obtained coefficients because, in the Weende's method, parts of the hemicellulose and the lignin are solubilized and become part of the nitrogen-free extract (Silva \& Queiroz, 2006).
The use of NDF and hemicellulose as indicators of digestibility provided lower ADCs for the DM, energy, and nutrients, in both diets $(\mathrm{p}<0.05)$, in comparison with the standard indicator $\mathrm{Cr}_{2} \mathrm{O}_{3}$ (Tables 3 and 4), which may be associated with the solubilization of pectin by the neutral detergent solution (Van Soest et al., 1991). Pectin constitutes the cell wall of plants, together with the structural carbohydrates (cellulose and hemicellulose) and lignin (Van Soest et al., 1991), and it is described by Brito et al. (2008) as nondigestible by monogastric animals. As pectin constitutes a relevant percentage of the cell wall of soybean meal (Queiroz et al., 2010), and this ingredient corresponds to the protein base of both diets, its solubilization may have affected the determination of the coefficients, when the NDF was used as an indicator. In turn, the hemicellulose, obtained by subtraction of NDF by ADF, may also have been changed by this solubilization.

Table 3. Apparent digestibility coefficients ${ }^{(1)}$ (ADC, \%) of dry matter, gross energy, and nutrients estimated using chromium (III) oxide $\left(\mathrm{Cr}_{2} \mathrm{O}_{3}\right)$, crude fiber (CF), neutral detergent fiber (NDF), acid detergent fiber (ADF), hemicellulose, cellulose, and lignin as indicators in Nile tilapia fed plant-origin $\operatorname{diet}^{(2)}$.

\begin{tabular}{|c|c|c|c|c|c|c|c|}
\hline Nutrient/ amino acids & $\mathrm{Cr}_{2} \mathrm{O}_{3}$ & $\mathrm{CF}$ & $\mathrm{NDF}$ & $\mathrm{ADF}$ & Hemicellulose & Cellulose & Lignin \\
\hline Dry matter & $76.77 \pm 0.24 \mathrm{a}$ & $82.3 \pm 0.24 \mathrm{~b}$ & $72.46 \pm 0.31 \mathrm{~b}$ & $75.93 \pm 0.31 \mathrm{a}$ & $70.09 \pm 0.55 b$ & $77.17 \pm 0.2 \mathrm{a}$ & $70.33 \pm 0.35 b$ \\
\hline Gross energy & $81.31 \pm 0.19 \mathrm{a}$ & $85.75 \pm 0.19 \mathrm{~b}$ & $77.83 \pm 0.25 b$ & $80.63 \pm 0.25 \mathrm{a}$ & $75.93 \pm 0.44 b$ & $81.63 \pm 0.16 \mathrm{a}$ & $76.12 \pm 0.28 b$ \\
\hline Crude protein & $94.79 \pm 0.11 \mathrm{a}$ & $96.03 \pm 0.05 b$ & $93.83 \pm 0.07 \mathrm{~b}$ & $94.61 \pm 0.02 \mathrm{a}$ & $93.3 \pm 0.14 \mathrm{~b}$ & $94.88 \pm 0.02 \mathrm{a}$ & $93.35 \pm 0.13 \mathrm{~b}$ \\
\hline Phosphorus & $51.23 \pm 0.83 \mathrm{a}$ & $62.81 \pm 1.02 \mathrm{~b}$ & $42.18 \pm 0.53 b$ & $49.44 \pm 1.16 \mathrm{a}$ & $37.23 \pm 0.26 \mathrm{~b}$ & $52.05 \pm 0.9 \mathrm{a}$ & $37.72 \pm 0.33 \mathrm{~b}$ \\
\hline \multicolumn{8}{|l|}{ Essential amino acids } \\
\hline Arginine & $97.39 \pm 0.04 \mathrm{a}$ & $98.01 \pm 0.07 \mathrm{~b}$ & $96.91 \pm 0.1 \mathrm{~b}$ & $97.29 \pm 0.11 \mathrm{a}$ & $96.64 \pm 0.11 b$ & $97.43 \pm 0.09 \mathrm{a}$ & $96.67 \pm 0.08 \mathrm{~b}$ \\
\hline Histidine & $97.93 \pm 0.02 \mathrm{a}$ & $98.42 \pm 0.02 \mathrm{~b}$ & $97.54 \pm 0.03 b$ & $97.85 \pm 0.03 \mathrm{a}$ & $97.33 \pm 0.05 b$ & $97.96 \pm 0.02 \mathrm{a}$ & $97.36 \pm 0.03 \mathrm{~b}$ \\
\hline Isoleucine & $92.35 \pm 0.01 \mathrm{a}$ & $94.17 \pm 0.13 b$ & $90.93 \pm 0.18 b$ & $92.07 \pm 0.2 \mathrm{a}$ & $90.15 \pm 0.22 b$ & $92.48 \pm 0.16 \mathrm{a}$ & $90.23 \pm 0.13 \mathrm{~b}$ \\
\hline Leucine & $95.94 \pm 0.02 \mathrm{a}$ & $96.91 \pm 0.08 \mathrm{~b}$ & $95.19 \pm 0.11 \mathrm{~b}$ & $95.79 \pm 0.12 \mathrm{a}$ & $94.78 \pm 0.12 b$ & $96.01 \pm 0.09 \mathrm{a}$ & $94.82 \pm 0.08 \mathrm{~b}$ \\
\hline Lysine & $96.27 \pm 0.11 \mathrm{a}$ & $97.16 \pm 0.04 b$ & $95.58 \pm 0.07 \mathrm{~b}$ & $96.14 \pm 0.02 \mathrm{a}$ & $95.2 \pm 0.12 \mathrm{~b}$ & $96.34 \pm 0.03 \mathrm{a}$ & $95.24 \pm 0.12 \mathrm{~b}$ \\
\hline Phenylalanine & $95.14 \pm 0.06 \mathrm{a}$ & $96.29 \pm 0.12 b$ & $94.23 \pm 0.17 b$ & $94.95 \pm 0.18 \mathrm{a}$ & $93.73 \pm 0.18 b$ & $95.21 \pm 0.15 \mathrm{a}$ & $93.79 \pm 0.13 \mathrm{~b}$ \\
\hline Methionine & $99.51 \pm 0 \mathrm{a}$ & $99.62 \pm 0.01 \mathrm{~b}$ & $99.42 \pm 0.01 \mathrm{~b}$ & $99.49 \pm 0.01 \mathrm{a}$ & $99.37 \pm 0.01 \mathrm{~b}$ & $99.52 \pm 0.01 \mathrm{a}$ & $99.37 \pm 0.01 \mathrm{~b}$ \\
\hline Threonine & $94.47 \pm 0.15 \mathrm{a}$ & $95.78 \pm 0.2 b$ & $93.44 \pm 0.28 b$ & $94.26 \pm 0.29 \mathrm{a}$ & $92.88 \pm 0.3 \mathrm{~b}$ & $94.56 \pm 0.25 \mathrm{a}$ & $92.94 \pm 0.24 b$ \\
\hline Tryptophan & $96.74 \pm 0.30 \mathrm{a}$ & $97.53 \pm 0.18 \mathrm{a}$ & $96.15 \pm 0.29 \mathrm{a}$ & $96.64 \pm 0.23 \mathrm{a}$ & $95.82 \pm 0.34 \mathrm{a}$ & $96.81 \pm 0.23 \mathrm{a}$ & $95.84 \pm 0.35 \mathrm{a}$ \\
\hline Valine & $92.18 \pm 0.01 \mathrm{a}$ & $94.04 \pm 0.14 b$ & $90.72 \pm 0.18 \mathrm{~b}$ & $91.89 \pm 0.2 \mathrm{a}$ & $89.93 \pm 0.22 b$ & $92.31 \pm 0.16 \mathrm{a}$ & $90.01 \pm 0.13 \mathrm{~b}$ \\
\hline \multicolumn{8}{|c|}{ Nonessential amino acids } \\
\hline Alanine & $94.04 \pm 0.04 \mathrm{a}$ & $95.45 \pm 0.12 b$ & $92.93 \pm 0.17 b$ & $93.82 \pm 0.18 \mathrm{a}$ & $92.32 \pm 0.19 \mathrm{~b}$ & $94.14 \pm 0.15 \mathrm{a}$ & $92.38 \pm 0.12 \mathrm{~b}$ \\
\hline Aspartic acid & $98.61 \pm 0.08 \mathrm{a}$ & $98.94 \pm 0.08 \mathrm{a}$ & $98.35 \pm 0.12 \mathrm{a}$ & $98.56 \pm 0.12 \mathrm{a}$ & $98.21 \pm 0.13 \mathrm{a}$ & $98.63 \pm 0.11 \mathrm{a}$ & $98.23 \pm 0.12 \mathrm{a}$ \\
\hline Cystine & $94.63 \pm 0.05 \mathrm{a}$ & $95.91 \pm 0.06 \mathrm{~b}$ & $93.63 \pm 0.08 \mathrm{~b}$ & $94.44 \pm 0.08 \mathrm{a}$ & $93.09 \pm 0.13 b$ & $94.72 \pm 0.06 \mathrm{a}$ & $93.14 \pm 0.08 \mathrm{~b}$ \\
\hline Glycine & $92.92 \pm 0.36 \mathrm{a}$ & $94.59 \pm 0.38 \mathrm{a}$ & $91.59 \pm 0.56 \mathrm{a}$ & $92.64 \pm 0.54 \mathrm{a}$ & $90.87 \pm 0.58 \mathrm{~b}$ & $93.02 \pm 0.48 \mathrm{a}$ & $90.95 \pm 0.51 \mathrm{a}$ \\
\hline Glutamic acid & $98.34 \pm 0.02 \mathrm{a}$ & $98.73 \pm 0.04 \mathrm{~b}$ & $98.03 \pm 0.06 \mathrm{~b}$ & $98.28 \pm 0.06 \mathrm{a}$ & $97.86 \pm 0.06 \mathrm{~b}$ & $98.37 \pm 0.05 \mathrm{a}$ & $97.88 \pm 0.05 b$ \\
\hline Proline & $95.68 \pm 0.07 \mathrm{a}$ & $96.71 \pm 0.12 b$ & $94.88 \pm 0.17 b$ & $95.52 \pm 0.17 \mathrm{a}$ & $94.44 \pm 0.18 \mathrm{~b}$ & $95.75 \pm 0.15 \mathrm{a}$ & $94.49 \pm 0.13 \mathrm{~b}$ \\
\hline Serine & $95.62 \pm 0.1 \mathrm{a}$ & $96.66 \pm 0.14 b$ & $94.8 \pm 0.20 \mathrm{~b}$ & $95.45 \pm 0.2 \mathrm{a}$ & $94.35 \pm 0.21 b$ & $95.69 \pm 0.18 \mathrm{a}$ & $94.4 \pm 0.16 \mathrm{~b}$ \\
\hline Tyrosine & $94.14 \pm 0.15 \mathrm{a}$ & $95.53 \pm 0.20 \mathrm{~b}$ & $93.04 \pm 0.29 \mathrm{~b}$ & $93.91 \pm 0.29 \mathrm{a}$ & $92.44 \pm 0.3 \mathrm{~b}$ & $94.23 \pm 0.26 \mathrm{a}$ & $92.51 \pm 0.24 \mathrm{~b}$ \\
\hline
\end{tabular}

${ }^{(1)}$ Mean \pm standard error of the mean $(n=3)$. (2) Means followed by equal letters, in the rows, do not differ from one another by the Dunnett's test, at $5 \%$ probability. 
Table 4. Apparent digestibility coefficients ${ }^{(1)}$ (ADC, \%) of dry matter, gross energy, and nutrients estimated using the external indicator chromium (III) oxide $\left(\mathrm{Cr}_{2} \mathrm{O}_{3}\right)$, and the internal indicators crude fiber (CF), neutral detergent fiber (NDF), acid detergent fiber (ADF), hemicellulose, cellulose, and lignin as indicators in Nile tilapia fed animal- and plant-origin $\operatorname{diet}^{(2)}$.

\begin{tabular}{|c|c|c|c|c|c|c|c|}
\hline Nutrient/ amino acids & $\mathrm{Cr}_{2} \mathrm{O}_{3}$ & $\mathrm{CF}$ & $\mathrm{NDF}$ & $\mathrm{ADF}$ & Hemicellulose & Cellulose & Lignin \\
\hline Dry matter & $74.67 \pm 0.6 \mathrm{a}$ & $80.62 \pm 0.84 b$ & $68.94 \pm 0.37 \mathrm{~b}$ & $66.83 \pm 0.75 b$ & $70.17 \pm 0.64 b$ & $71.39 \pm 1.03 a$ & $61.88 \pm 1.27 \mathrm{~b}$ \\
\hline Gross energy & $79.14 \pm 0.49 \mathrm{a}$ & $84.04 \pm 0.69 b$ & $74.43 \pm 0.31 \mathrm{~b}$ & $72.69 \pm 0.61 b$ & $75.44 \pm 0.52 b$ & $76.44 \pm 0.85 \mathrm{a}$ & $68.61 \pm 1.04 \mathrm{~b}$ \\
\hline Crude protein & $92.38 \pm 0.08 \mathrm{a}$ & $94.18 \pm 0.17 b$ & $90.66 \pm 0.14 b$ & $90.03 \pm 0.08 \mathrm{~b}$ & $91.02 \pm 0.26 \mathrm{~b}$ & $91.4 \pm 0.2 b$ & $88.53 \pm 0.47 b$ \\
\hline Phosphorus & $55.13 \pm 1.82 \mathrm{a}$ & $65.66 \pm 2 \mathrm{~b}$ & $45.03 \pm 1.46 \mathrm{~b}$ & $41.27 \pm 2.26 \mathrm{~b}$ & $47.21 \pm 1.49 \mathrm{a}$ & $49.32 \pm 2.53 \mathrm{a}$ & $32.55 \pm 2.46 \mathrm{~b}$ \\
\hline \multicolumn{8}{|l|}{ Essential amino acids } \\
\hline Arginine & $96.55 \pm 0.03 \mathrm{a}$ & $97.36 \pm 0.04 \mathrm{~b}$ & $95.76 \pm 0.11 \mathrm{~b}$ & $95.48 \pm 0.03 \mathrm{~b}$ & $95.93 \pm 0.16 \mathrm{~b}$ & $96.1 \pm 0.06 \mathrm{a}$ & $94.79 \pm 0.27 b$ \\
\hline Histidine & $97.02 \pm 0.02 \mathrm{a}$ & $97.72 \pm 0.04 \mathrm{~b}$ & $96.35 \pm 0.09 b$ & $96.1 \pm 0.02 b$ & $96.49 \pm 0.14 \mathrm{~b}$ & $96.64 \pm 0.05 \mathrm{a}$ & $95.51 \pm 0.23 b$ \\
\hline Isoleucine & $87.74 \pm 0.12 \mathrm{a}$ & $90.63 \pm 0.14 b$ & $84.96 \pm 0.42 b$ & $83.95 \pm 0.14 b$ & $85.54 \pm 0.59 \mathrm{~b}$ & $86.17 \pm 0.2 \mathrm{a}$ & $81.52 \pm 0.97 \mathrm{~b}$ \\
\hline Leucine & $92.92 \pm 0.04 \mathrm{a}$ & $94.58 \pm 0.12 b$ & $91.31 \pm 0.18 b$ & $90.72 \pm 0.03 \mathrm{~b}$ & $91.65 \pm 0.29 \mathrm{~b}$ & $92 \pm 0.14 \mathrm{a}$ & $89.32 \pm 0.5 b$ \\
\hline Lysine & $94.14 \pm 0.04 \mathrm{a}$ & $95.52 \pm 0.08 b$ & $92.81 \pm 0.18 b$ & $92.33 \pm 0.05 b$ & $93.09 \pm 0.27 b$ & $93.39 \pm 0.1 \mathrm{a}$ & $91.17 \pm 0.44 b$ \\
\hline Phenylalanine & $92.12 \pm 0.08 \mathrm{a}$ & $93.97 \pm 0.18 b$ & $90.33 \pm 0.15 b$ & $89.68 \pm 0.09 b$ & $90.71 \pm 0.27 \mathrm{~b}$ & $91.1 \pm 0.21 b$ & $88.12 \pm 0.49 b$ \\
\hline Methionine & $99.09 \pm 0.02 \mathrm{a}$ & $99.31 \pm 0.03 b$ & $98.89 \pm 0.01 \mathrm{~b}$ & $98.81 \pm 0.03 b$ & $98.93 \pm 0.02 b$ & $98.98 \pm 0.04 \mathrm{a}$ & $98.64 \pm 0.05 b$ \\
\hline Threonine & $93.49 \pm 0.05 \mathrm{a}$ & $95.02 \pm 0.13 b$ & $92.02 \pm 0.15 b$ & $91.48 \pm 0.04 \mathrm{~b}$ & $92.33 \pm 0.24 b$ & $92.65 \pm 0.15 \mathrm{a}$ & $90.2 \pm 0.43 b$ \\
\hline Tryptophan & $89.3 \pm 2.94 \mathrm{a}$ & $91.74 \pm 2.44 \mathrm{a}$ & $87.01 \pm 3.35 \mathrm{a}$ & $86 \pm 3.88 \mathrm{a}$ & $87.59 \pm 3.07 \mathrm{a}$ & $87.86 \pm 3.51 \mathrm{a}$ & $84.21 \pm 3.78 \mathrm{a}$ \\
\hline Valine & $88.09 \pm 0.21 \mathrm{a}$ & $90.89 \pm 0.33 b$ & $85.39 \pm 0.17 b$ & $84.41 \pm 0.25 b$ & $85.97 \pm 0.34 \mathrm{~b}$ & $86.55 \pm 0.4 \mathrm{~b}$ & $82.07 \pm 0.65 \mathrm{~b}$ \\
\hline \multicolumn{8}{|c|}{ Nonessential amino acids } \\
\hline Alanine & $91.32 \pm 0.06 \mathrm{a}$ & $93.36 \pm 0.12 b$ & $89.35 \pm 0.26 b$ & $88.63 \pm 0.06 \mathrm{~b}$ & $89.76 \pm 0.38 b$ & $90.2 \pm 0.16 \mathrm{a}$ & $86.91 \pm 0.64 b$ \\
\hline Aspartic acid & $97.71 \pm 0.08 \mathrm{a}$ & $98.25 \pm 0.10 \mathrm{~b}$ & $97.19 \pm 0.05 b$ & $97 \pm 0.1 b$ & $97.30 \pm 0.06 \mathrm{~b}$ & $97.41 \pm 0.12 \mathrm{a}$ & $96.56 \pm 0.1 \mathrm{~b}$ \\
\hline Cystine & $87.45 \pm 0.95 \mathrm{a}$ & $90.43 \pm 0.56 \mathrm{a}$ & $84.55 \pm 1.45 \mathrm{a}$ & $83.56 \pm 1.26 \mathrm{a}$ & $85.13 \pm 1.55 \mathrm{a}$ & $85.85 \pm 0.97 \mathrm{a}$ & $80.97 \pm 2.15 b$ \\
\hline Glycine & $91.73 \pm 0.14 \mathrm{a}$ & $93.68 \pm 0.06 \mathrm{~b}$ & $89.85 \pm 0.36 b$ & $89.18 \pm 0.18 b$ & $90.24 \pm 0.47 \mathrm{a}$ & $90.67 \pm 0.14 \mathrm{a}$ & $87.52 \pm 0.74 b$ \\
\hline Glutamic acid & $97.44 \pm 0.02 \mathrm{a}$ & $98.04 \pm 0.04 \mathrm{~b}$ & $96.86 \pm 0.08 \mathrm{~b}$ & $96.65 \pm 0.02 \mathrm{~b}$ & $96.98 \pm 0.11 \mathrm{~b}$ & $97.11 \pm 0.05 \mathrm{a}$ & $96.14 \pm 0.19 b$ \\
\hline Proline & $94 \pm 0.05 \mathrm{a}$ & $95.41 \pm 0.12 b$ & $92.64 \pm 0.13 b$ & $92.14 \pm 0.04 \mathrm{~b}$ & $92.93 \pm 0.22 b$ & $93.22 \pm 0.14 \mathrm{a}$ & $90.96 \pm 0.39 b$ \\
\hline Serine & $93.72 \pm 0.15 \mathrm{a}$ & $95.21 \pm 0.05 b$ & $92.29 \pm 0.34 b$ & $91.78 \pm 0.2 b$ & $92.59 \pm 0.41 \mathrm{a}$ & $92.92 \pm 0.14 \mathrm{a}$ & $90.52 \pm 0.63 b$ \\
\hline Tyrosine & $91.33 \pm 0.11 \mathrm{a}$ & $93.37 \pm 0.21 \mathrm{~b}$ & $89.37 \pm 0.15 b$ & $88.65 \pm 0.12 b$ & $89.78 \pm 0.28 b$ & $90.21 \pm 0.25 b$ & $86.94 \pm 0.52 b$ \\
\hline
\end{tabular}

${ }^{(1)}$ Mean \pm standard error of the mean ( $\left.\mathrm{n}=3\right)$. (2) Means followed by equal letters, in the rows, do not differ from one another by the Dunnett's test, at $5 \%$ probability.

As observed with the use of NDF and hemicellulose, the use of lignin as an indicator of digestibility resulted in lower ADCs for the DM, energy, and nutrients $(\mathrm{p}<0.05)$, except for the values obtained for the amino acids tryptophan, aspartic acid, and glycine of the diet with exclusively plant-origin ingredients (Tables 3 and 4).

The ADF and the cellulose were effective in determining the $\mathrm{ADC}$ of the $\mathrm{DM}$, energy, and nutrients of the diet that contained exclusively plant-origin ingredients. Regarding the diet with animal- and plant-origin ingredients, only cellulose was effective in determining the ADCs. This result indicates the possible interference of the ingredients of animalorigin in the determination of the components evaluated as internal indicators. Furthermore, it indicates the importance of subsequently evaluating diets that contain higher levels of inclusion of animal-origin ingredients, in order to verify the possible influence of these ingredients on determinations of the dietary cellulose and, therefore, the validity of cellulose as an internal indicator of digestibility.

\section{Conclusions}

1. Dietary cellulose is effective in determining the apparent digestibility components of dry matter, gross energy, and nutrients of diets that exclusively contain plant-origin ingredients, or animal- and plant-origin ingredients.

2. Acid detergent fiber is effective as an indicator of digestibility only for the diet with plant-origin ingredients.

3. The use of crude fiber, neutral detergent fiber, hemicellulose, and lignin is not effective in the estimation of the apparent digestibility coefficients of dry matter, gross energy, and nutrients, irrespective of the diet composition. 


\section{Acknowledgments}

To Fundação de Amparo à Pesquisa do Estado de São Paulo (Fapesp), for financial support (Process No. 2014/16484-0).

\section{References}

ABIMORAD, E.G.; CASTELLANI, D.; GONÇALVES, G.S.; ROMERA, D.M.; GARCIA, F.; NASCIMENTO, T.M.T. do. Substituição parcial do farelo de soja pela farinha de carne e ossos em dietas para juvenis de tilápia-do-nilo. Pesquisa Agropecuária Brasileira, v.49, p.836-843, 2014. DOI: 10.1590/ S0100-204X2014001100002.

AMIRKOLAIE, A.K.; LEENHOUWERS, J.I.; VERRETH, J.A.J.; SCHRAMA, J.W. Type of dietary fibre (soluble versus insoluble) influences digestion, faeces characteristics and faecal waste production in Nile tilapia (Oreochromis niloticus L.). Aquaculture Research, v.36, p.1157-1166, 2005. DOI: 10.1111/j.1365-2109.2005.01330.x.

BREMER NETO, H.; GRANER, C.A.F.; PEZZATO, L.E.; PADOVANI, C.R. Determinação de rotina do crômio em fezes, como marcador biológico, pelo método espectrofotométrico ajustado da 1,5-difenilcarbazida. Ciência Rural, v.35, p.691-697, 2005. DOI: 10.1590/S0103-84782005000300033.

BRITO, M.S. de; OLIVEIRA, C.F.S. de; SILVA, T.R.G. da; LIMA, R.B. de; MORAIS, S.N.; SILVA, J.H.V. da. Polissacarídeos não amiláceos na nutrição de monogástricos - revisão. Acta Veterinaria Brasilica, v.2, p.111-117, 2008. DOI: 10.21708/ avb.2008.2.4.917

BUDDINGTON, R.K. Hydrolysis-resistant organic matter as a referenceformeasurement offish digestive efficiency. Transactions of the American Fisheries Society, v.109, p.653-656, 1980. DOI: 10.1577/1548-8659(1980)109<653:HOMAAR>2.0.CO;2.

BUREAU, D.P.; HUA, K. Letter to the editor of Aquaculture. Aquaculture, v.252, p.103-105, 2006. DOI: 10.1016/j. aquaculture.2006.01.028.

CYRINO, J.E.P.; BICUDO, Á.J. de A.; SADO, R.Y.; BORGHESI, R.; DAIRIKI, J.K. A piscicultura e o ambiente: o uso de alimentos ambientalmente corretos em piscicultura. Revista Brasileira de Zootecnia, v.39, p.68-87, 2010. DOI: 10.1590/S151635982010001300009 .

DA, C.T.; LUNDH, T.; LINDBERG, J.E. Digestibility of dietary components and amino acids in plant protein feed ingredients in striped catfish (Pangasianodon hypophthalmus) fingerlings. Aquaculture Nutrition, v.19, p.619-628, 2013. DOI: 10.1111/ anu.12011.

FURUYA, W.M. (Ed.). Tabelas brasileiras para a nutrição de tilápias. Toledo: GFM, 2010. 100p.

FURUYA, W.M.; SILVA, L.C.R.; NEVES, P.R.; BOTARO, D.; HAYASHI, C.; FURLAN, A.C.; SANTOS, V.G. dos. Coeficientes de digestibilidade aparente da energia e proteína da silagem de sorgo com alto e baixo tanino pela tilápia do nilo (Oreochromis niloticus). Ciência Rural, v.34, p.1213-1217, 2004. DOI: 10.1590/ S0103-84782004000400038.

GOÑI, I.; DÍAZ-RUBIO, M.E.; PÉREZ-JIMÉNEZ, J.; SAURACALIXTO, F. Towards an updated methodology for measurement of dietary fiber, including associated polyphenols, in food and beverages. Food Research International, v.42, p.840-846, 2009. DOI: 10.1016/j.foodres.2009.03.010.

GUIMARÃES, I.G.; MIRANDA, E.C. de; MARTINS, G.P.; LOURO, V.R.; MIRANDA, C.C. de. Farinha de camarão em dietas para tilápia do Nilo (Oreochromis niloticus). Revista Brasileira de Saúde e Produção Animal, v.9, p.140-149, 2008a.

GUIMARÃES, I.G.; PEZZATO, L.E.; BARROS, M.M. Amino acid availability and protein digestibility of several protein sources for Nile tilapia, Oreochromis niloticus. Aquaculture Nutrition, v.14, p.396-404, 2008b. DOI: 10.1111/j.1365-2095.2007.00540.x.

GUIMARÃES, I.G.; PEZZATO, L.E.; BARROS, M.M.; TACHIBANA, L. Nutrient digestibility of cereal grain products and by-products in extruded diets for Nile tilapia. Journal of the World Aquaculture Society, v.39, p.781-789, 2008c. DOI: 10.1111/j.1749-7345.2008.00214.x.

HERNÁNDEZ, C.; OLVERA-NOVOA, M.A.; HARDY, R.W.; HERMOSIllO, A.; REYES, C.; GONZÁlES, B. Complete replacement of fish meal by porcine and poultry by-product meals in practical diets for fingerling Nile tilapia Oreochromis niloticus: digestibility and growth performance. Aquaculture Nutrition, v.16, p.44-53, 2010. DOI: 10.1111/j.1365-2095.2008.00639.x.

KROGDAHL, Å.; HEMRE, G.-I.; MOMMSEN, T.P. Carbohydrates in fish nutrition: digestion and absorption in postlarval stages. Aquaculture Nutrition, v.11, p.103-122, 2005. DOI: $10.1111 /$ j.1365-2095.2004.00327.x.

KRONTVEIT, R.I.; BENDIKSEN, E.Å.; AUNSMO, A. Field monitoring of feed digestibility in Atlantic salmon farming using crude fiber as an inert marker. Aquaculture, v.426-427, p.249255, 2014. DOI: 10.1016/j.aquaculture.2014.02.015.

LI, P.; WEBB, K.A.; GATLIN III, D.M. Evaluation of acid-insoluble ash as an indicator for digestibility determination with red drum, Sciaenops ocellatus, and hybrid striped bass, Morone chrysops $\times$ M. saxatilis. Journal of the World Aquaculture Society, v.39, p.120-125, 2008. DOI: 10.1111/j.1749-7345.2007.00144.x.

MAYNARD, L.A.; LOOSLI, J.K. Animal nutrition. $6^{\text {th }}$ ed. New York: McGraw-Hill, 1969. 613p.

MICHELATO, M.; FURUYA, W.M.; GRACIANO, T.S.; VIDAL, L.V.O.; XAVIER, T.O.; MOURA, L.B. de; FURUYA, V.R.B. Digestible methionine + cystine requirement for Nile tilapia from 550 to 700 g. Revista Brasileira de Zootecnia, v.42, p.7-12, 2013. DOI: $10.1590 / \mathrm{S} 1516-35982013000100002$.

MORAES, P.M. de; LOUREIRO, V.R.; PADILHA, P.M.; NEVES, R. de C.F.; SALEH, M.A.D.; SANTOS, F.A. dos; SILVA, F.A. Determinação de fósforo biodisponível em rações de peixes utilizando extração assistida por ultra-som e espectrofotometria no visível. Química Nova, v.32, p.923-927, 2009. DOI: 10.1590/ S0100-40422009000400018.

MORALES, A.E.; CARDENETE, G.; SANZ, A.; HIGUERA, $\mathrm{M}$. Re-evaluation of crude fibre and acid-insoluble ash as inert 
markers, alternative to chromic oxide, in digestibility studies with rainbow trout (Oncorhynchus mykiss). Aquaculture, v.179, p.7179, 1999. DOI: 10.1016/S0044-8486(99)00153-2.

QUEIROZ, M.A.Á.; SUSIN, I.; PIRES, A.V.; FERREIRA, E.M.; MENDES, C.Q.; MOURÃO, G.B. Características físico-químicas de fontes proteicas e suas interações sobre a degradação ruminal e a taxa de passagem. Revista Brasileira de Zootecnia, v.39, p.1587-1594, 2010. DOI: 10.1590/S1516-35982010000700027.

SAHA, S.; ROY, R.N.; SEN, S.K.; RAY, A.K. Characterization of cellulase-producing bacteria from the digestive tract of tilapia, Oreochromis mossambica (Peters) and grass carp, Ctenopharyngodonidella (Valenciennes). Aquaculture Research, v.37, p.380-388, 2006. DOI: 10.1111/j.1365-2109.2006.01442.x.

SILVA, D.J.; QUEIROZ, A.C. de. Análise de alimentos: métodos químicos e biológicos. 3.ed. Viçosa: Ed. da UFV, 2006. 235p.

TACON, A.G.J.; METIAN, M. Fish matters: importance of aquatic foods in human nutrition and global food supply. Reviews in Fisheries Science, v.21, p.22-38, 2013. DOI: 10.1080/10641262.2012.753405.

VAN SOEST, P.J.; ROBERTSON, J.B.; LEWIS, B.A. Methods for dietary fiber, neutral detergent fiber, and nonstarch polysaccharides in relation to animal nutrition. Journal of Dairy Science, v.74, p.3583-3597, 1991. DOI: 10.3168/jds.S0022-0302(91)78551-2.

VIDAL JUNIOR, M.V.; DONZELE, J.L.; ANDRADE, D.R. de; SANTOS, L.C. dos. Determinação da digestibilidade da matéria seca e da proteína bruta do fubá de milho e do farelo de soja para tambaqui (Colossoma macropomum), utilizando-se técnicas com uso de indicadores internos e externos. Revista Brasileira de Zootecnia, v.33, p.2193-2200, 2004. DOI: 10.1590/S151635982004000900003.

VIDAL, L.V.O.; XAVIER, T.O.; MICHELATO, M.; MARTINS, E.N.; PEZZATO, L.E.; FURUYA, W.M. Apparent protein and energy digestibility and amino acid availability of corn and coproducts in extruded diets for Nile tilapia, Oreochromis niloticus. Journal of the World Aquaculture Society, v.46, p.183-190, 2015. DOI: $10.1111 /$ jwas.12184.

XAVIER, T.O.; MICHELATO, M.; VIDAL, L.V.O.; FURUYA, V.R.B.; FURUYA, W.M. Apparent protein and energy digestibility and amino acid availability of commercial meat and bone meal for Nile tilapia, Oreochromis niloticus. Journal of the World Aquaculture Society, v.45, p.439-446, 2014. DOI: 10.1111/ jwas.12127.

Received on August 10, 2016 and accepted on October 18, 2016 